\title{
Histopathological and Clinical Correlation of Hyperpigmented Skin Lesions
}

\author{
Dr. Sneha Ravindran ${ }^{1}$, Dr. Kalla Ravi Teja ${ }^{2^{*}}$, Dr. Arun Kumar $\mathrm{SP}^{3}$, Dr. Jonathan Arnold ${ }^{4}$, Dr. Balaji $\mathrm{S}^{4}$
}

${ }^{1}$ Post Graduate, Department of Pathology, SVMCH, Puducherry, India

${ }^{2}$ Assistant Professor, Department of Pathology, SVMCH, Puducherry, India

${ }^{3}$ Professor and HOD, Department of Pathology, SVMCH, Puducherry, India

${ }^{4}$ Associate Professor, Department of Pathology, SVMCH, Puducherry, India

${ }^{5}$ Post Graduate, Department of Pathology, SVMCH, Puducherry, India

DOI: $\underline{10.36347 / \text { sjams.2020.v08i11.007 }}$

| Received: 16.10.2020 | Accepted: 30.10.2020 | Published: 12.11 .2020

*Corresponding author: Dr. Sneha Ravindran

Abstract

Introduction: The spectrum of clinical disease related to hyperpigmented lesion is wider. The most common hyperpigmented skin lesion is lichen planus and its variants. Histopathological examination helps to derive an accurate tissue reaction. Pathologic examination often serves as a confirmative diagnosis for skin lesions. The histology-based treatment will be helpful for establishing a standardized management for hyperpigmentary skin lesions. Materials and Methods: A total of 100 patients with hyperpigmented punch skin biopsy lesions in all age groups following inclusion and exclusion criteria is taken and examined for histopathological correlation from the Department of Pathology. Result: In this study of hyperpigmented skin lesions the maximum number of cases $45(45 \%)$ were those of classical Lichen planus and its variants, followed by $12 \%$ of eczematoid dermatitis, $8 \%$ of PMLE, $7 \%$ of DLE, $6 \%$ of lichen simplex chronicus, $7 \%$ of post inflammatory hyperpigmentation, $3 \%$ of prurigo nodularis, $4 \%$ of prurigo simplex, morphea $4 \%$, acne $3 \%$, and $1 \%$ of erythema dyschromium perstans. $90 \%$ cases show histopathological correlation and $10 \%$ cases were diagnosed only on histology based. Conclusion: Lichen planus and its variants are most common hyperpigmentary skin lesions found in the study population. The pathologist ability to render an accurate diagnosis depends on the available clinical evaluation details.

Keywords: Lichen planus, basal cell damage, DLE, PMLE, interface dermatitis.

Copyright (C) 2020 The Author(s): This is an open-access article distributed under the terms of the Creative Commons Attribution 4.0 International License (CC BY-NC 4.0) which permits unrestricted use, distribution, and reproduction in any medium for non-commercial use provided the original author and source are credited.

\section{INTRODUCTION}

The skin is the largest organ of body, accounting for around $15 \%$ of the total body weight in a human adult [1].

The importance of accurate diagnosis is emphasized here as the underlying diseases have varying etiologies that need to be accurately diagnosed in order to effectively treat the hyper pigmentary lesions. In this review, we discuss and describe the utility of histology in the diagnosing of hyper pigmentary disorders and how, in many cases, it can lead to targeted and more effective therapy. We focus on the most common hyper pigmentary disorders seen in Indian patients [2].

Pigmentary problems is one of the most frequent causes for dermatologic consultation. Disorders of pigmentation can result from migration abnormalities of melanocytes from neural crest to the skin during embryogenesis, impairment of melanosome transfer to keratinocytes and alteration in melanin synthesis. Although high melanin content confers better photo protection, photo damage in the form of pigmentary disorders is quite common [2].

Hyperpigmentation is not only a cosmetic problem causing psychological upset but can also reflect underlying organ dysfunction at times. The cause of hyperpigmentation usually can be traced to the presence of activity of melanocyte when the patient seeks medical attention for skin lesions, the physician requires an accurate diagnosis in order to institute proper treatment. However, the clinical diagnosis of skin diseases may be challenging, as the clinical information and appearance of skin lesions invariably overlap. Evidence for a correct diagnosis is often difficult without histopathologic examination of skin biopsies. It is well known that the histologic diagnosis of inflammatory and other skin diseases requires clinicopathologic correlation, and there is evolution of 
skin lesions into different stages as the disease progresses. Histopathologic examination often serves as a confirmative and complimentary part of the diagnosis. The histology-based treatment and management may be helpful for establishing an more accurate treatment protocol for hyperpigmentary skin lesions [3].

Acquired pigmentary disorders are found all over the world. Classic morphologies of these lesions have been reviewed in the global dermatology literature with an emphasis on treating these difficult diseases.

\section{Materials AND MethodS}

Aim

To study the histopathology of hyperpigmented skin lesions and its clinical correlation.

\section{Objectives}

1. To confirm the clinical diagnosis of hyperpigmented lesion with histopathological diagnosis.

2. To study the incidence of hyperpigmented lesions in the study population.

\section{Study Area}

The study was carried out among patients presenting with hyperpigmented skin lesion from rural population of Pondicherry.

\section{Study Design: Descriptive study}

Sample Size: 100 cases with hyperpigmented lesions.

Inclusion Criteria: Biopsy of patients clinically diagnosed as hyperpigmented lesion.

Exclusion Criteria: Patients with bleeding diathesis.

\section{METHODOLOGY}

The study was carried out in the Department of Pathology and Dermatology, Sri Venkateshwara Medical College Hospital \& Research Institute, Puducherry. Skin biopsies of the patients clinically diagnosed as hyperpigmented lesions after satisfying inclusion and exclusion criteria was studied.

\section{Biopsy Technique}

Biopsy is taken from the lesion. The site is cleaned and painted with an antiseptic solution and adequate amount of local anesthetic ( $2 \%$ lidocaine) is injected to the skin and subcutaneous tissue. A specimen obtained with a $4 \mathrm{~mm}$ biopsy punch is adequate for histologic study and then placed in $10 \%$ formalin.

\section{Examination}

A three dimensional size and shape gross examination done followed by routine processing and embedding in paraffin wax. 3-5microns thick paraffin sections were stained with Hematoxylin and Eosin. Stained slides will be viewed under the microscope to study the histopathological features. Epidermal and dermal changes will be noted. Also focal or diffuse nature of the lesion, pigment incontinence and appendageal involvement will be recorded.

\section{Statistical Analysis Age Distribution}

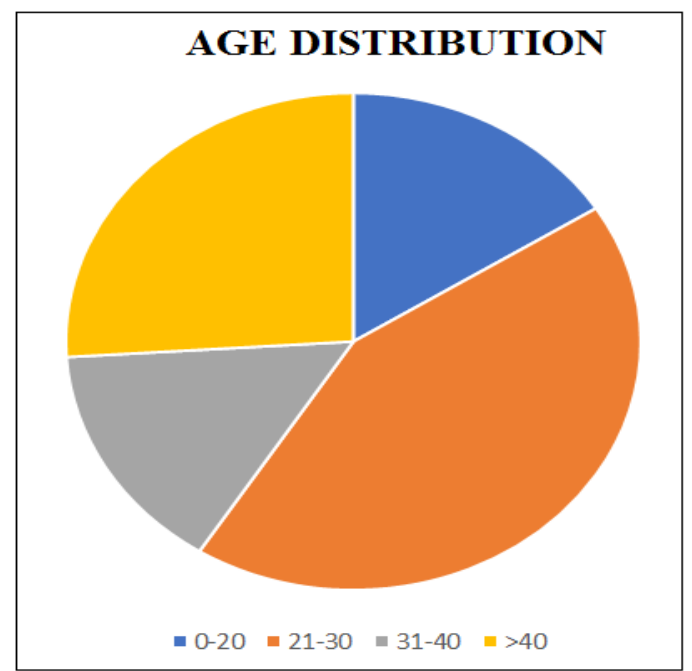

\begin{tabular}{|l|l|}
\hline Age ( years) & Percentage of distribution \\
\hline Birth -10 & 3 \\
\hline $11-20$ & 13 \\
\hline $21-30$ & 43 \\
\hline $31-40$ & 15 \\
\hline $41-50$ & 11 \\
\hline$>50$ & 15 \\
\hline
\end{tabular}

SEX DISTRIBUTION OF HYPERPIGMENTED SKIN LESIONS

\begin{tabular}{|l|l|l|l|l|}
\hline Age (years) & Male Patients & Female Patients & Total & Percentage of distribution \\
\hline Birth -10 & 2 & 1 & 3 & $\mathbf{3}$ \\
\hline $1-20$ & 5 & 8 & 13 & $\mathbf{1 3}$ \\
\hline $21-30$ & 20 & 23 & 43 & $\mathbf{4 3}$ \\
\hline $31-40$ & 7 & 8 & 15 & $\mathbf{1 5}$ \\
\hline $41-50$ & 4 & 7 & 11 & $\mathbf{1 1}$ \\
\hline$>50$ & 9 & 6 & 15 & $\mathbf{1 5}$ \\
\hline & $\mathbf{4 7}$ & $\mathbf{5 3}$ & $\mathbf{1 0 0}$ & $\mathbf{1 0 0}$ \\
\hline
\end{tabular}


CLINICAL AND HISTOLOGICAL CORRELATION

\begin{tabular}{|l|l|l|}
\hline CLINICAL/ HISTOPATHOLOGY CORRELATION & CASES & PERCENTAGE OF DISTRIBUTION \\
\hline Cases correlated both clinically and histopathologically & 90 & 90 \\
\hline Diagnosis confirmed on histopathological features & 10 & 10 \\
\hline
\end{tabular}

\section{DISTRIBUTION OF THE CASES}

\begin{tabular}{|l|l|l|l|}
\hline Sl. No & Lesions & No. of cases & Percentage (\%) \\
\hline 01 & Classical -lichen planus & 24 & 24 \\
\hline 02 & Lichen planus hypertrophicus & 6 & 6 \\
\hline 03 & Lichen planus pigmentosus & 6 & 6 \\
\hline 04 & Lichenoid like keratosis and reaction & 7 & 7 \\
\hline 05 & Lichen amyloidosis & 2 & 2 \\
\hline 06 & Lichen simplex chronicus & 6 & 6 \\
\hline 07 & Erythema dyschromium perstans & 1 & 1 \\
\hline 08 & Prurigo nodularis & 3 & 3 \\
\hline 09 & Prurigo simplex & 4 & 4 \\
\hline 10 & Post inflammatory hyperpigmentation & 7 & 7 \\
\hline 11 & Discoid lupus erythematosus & 7 & 7 \\
\hline 12 & Eczematous dermatitis & 12 & 12 \\
\hline 13 & Polymorphous light eruption & 8 & 8 \\
\hline 14 & Morphea & 4 & 4 \\
\hline 15 & Acne & 3 & 3 \\
\hline & Total & 100 & 100 \\
\hline
\end{tabular}

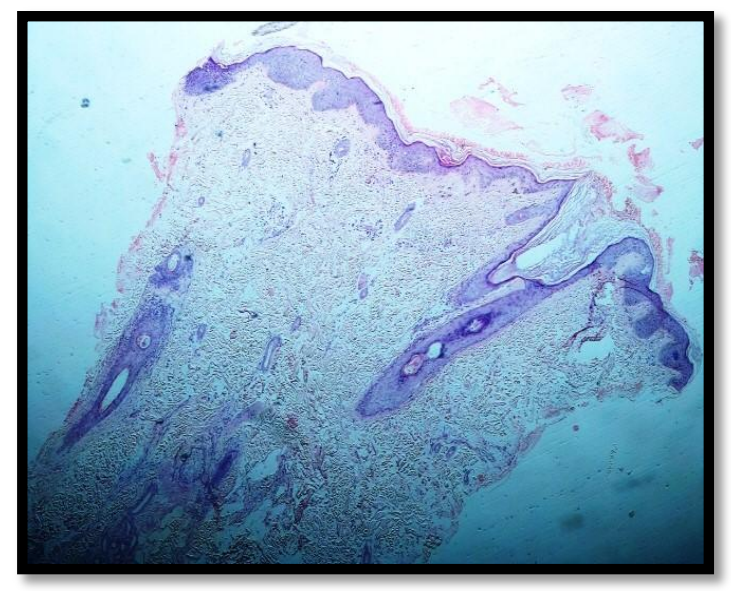

Fig-1: Lichen Plano Pilaris

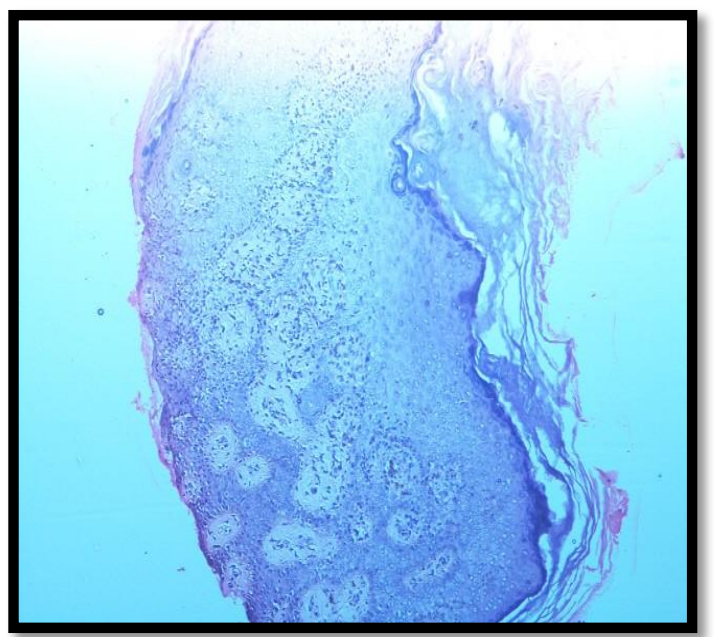

Fig-2: Lichen Nitidus

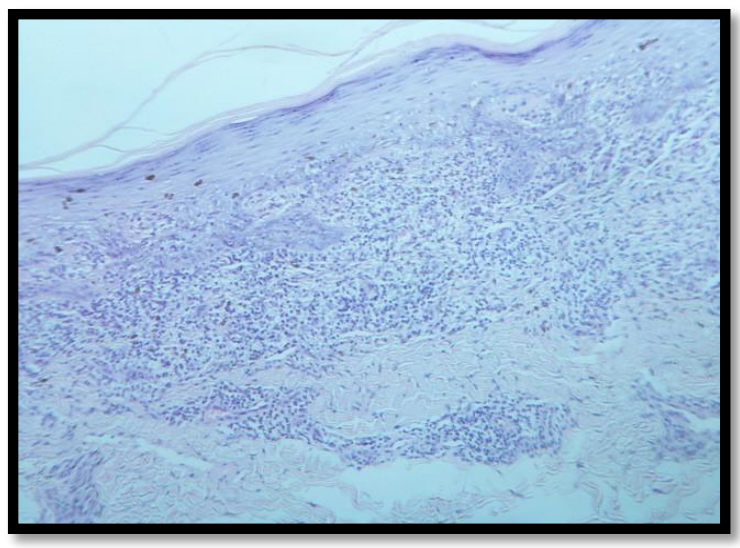

Fig-2: Lichenoid Dematitis

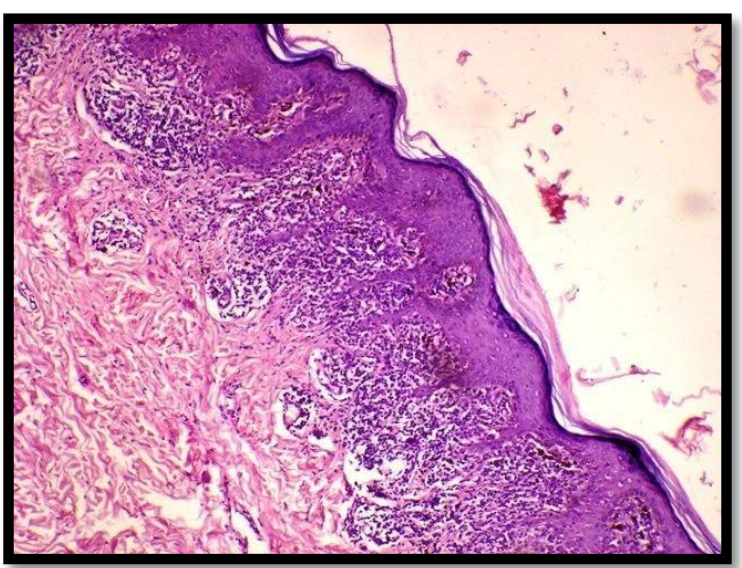

Fig-3: Lichen Planus 


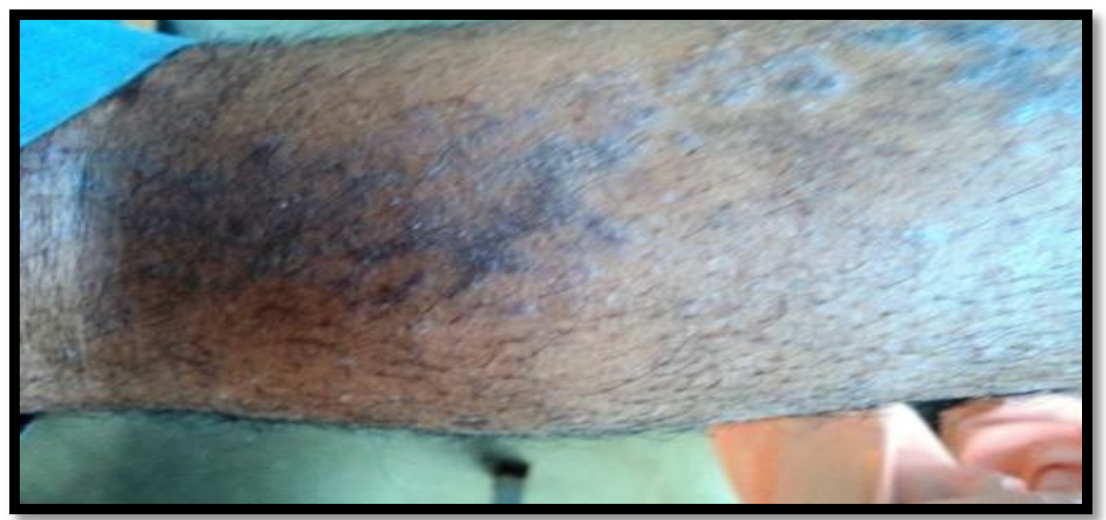

Fig-4: Lichen Planus Classical Purple Lesions

\begin{tabular}{|c|c|c|c|c|}
\hline $\begin{array}{l}\text { LICHENOID LESIONS } \\
\text { (45/100 CASES) }\end{array}$ & $\begin{array}{l}\text { PRESENT STUDY } \\
45 \text { CASES }\end{array}$ & $\begin{array}{l}\text { ELLIS FA et al., } \\
\text { (1967) [4] } \\
\text { 100 CASES }\end{array}$ & $\begin{array}{l}\text { SEHGAL VN } \\
\text { et al., (2011) [5] } \\
375 \text { CASES } \\
\end{array}$ & $\begin{array}{l}\text { SONTHEIMER RD } \text { et } \\
\text { al., (2009) [6] } \\
\text { 100 CASES }\end{array}$ \\
\hline COMMON AGE GROUP & $21-30$ years & $32-40$ years & $10-38$ years & $31-40$ years \\
\hline SEX PREDOMINANCE & Males & Males & Females & Females \\
\hline $\begin{array}{l}\text { ANATOMICAL } \\
\text { LOCATION }\end{array}$ & $\begin{array}{l}\text { Extremities, back and } \\
\text { trunk }\end{array}$ & $\begin{array}{l}\text { Upper extremities, } \\
\text { trunk, back and } \\
\text { genitalia }\end{array}$ & $\begin{array}{l}\text { Extremities and } \\
\text { back }\end{array}$ & $\begin{array}{l}\text { Trunk, back, face, oral } \\
\text { mucosa and Genitalia }\end{array}$ \\
\hline SIGNS AND SYMPTOMS & $\begin{array}{l}\text { Hyperpigmented Itchy } \\
\text { papules and macules }\end{array}$ & $\begin{array}{l}\text { Pruritic papules and } \\
\text { macules }\end{array}$ & $\begin{array}{l}\text { Flat topped } \\
\text { papules }\end{array}$ & Papules and macules \\
\hline
\end{tabular}

\section{RESUlT AND DiscuSSION}

Comparison of previous literature with present study

In this study of hyperpigmented skin lesions the maximum number of cases $45(45 \%)$ were those of classical lichen planus and its variants, followed by $12 \%$ of eczematoid dermatitis, $8 \%$ of PMLE, $7 \%$ of DLE, $6 \%$ of lichen simplex chronicum, $7 \%$ of post inflammatory hyperpigmentation, $3 \%$ of prurigo nodularis, $4 \%$ of prurigo simplex, morphea $4 \%$, acne $3 \%$, and $1 \%$ of erythema dyschromium perstans.
In diagnostic evaluation of a hyper pigmentary lesions further characterization of morphology, distribution, pattern and extent of the lesion are helpful to make an accurate initial clinical diagnosis and skin biopsy is needed to confirm the diagnosis.

In this study an analysis of the clinical diagnosis with the histopathological diagnosis revealed a positive correlation in $90 \%$ of cases and negative correlation in $10 \%$ of cases thus emphasizing the importance and utility of histopathology in arriving at a conclusive diagnosis.

\section{PREVELANCE OF CASES AMONG VARIOUS STUDIES}

\begin{tabular}{|c|c|c|c|c|}
\hline $\begin{array}{l}\text { PRESENT STUDY } 100 \\
\text { CASES }\end{array}$ & $\begin{array}{l}\text { STULBERG } \text { et } a l ., \\
(2003)[7] \\
100 \text { CASES }\end{array}$ & $\begin{array}{l}\text { PLENSDORF S } \text { et al., } \\
(2007)[8] \\
60 \text { CASES }\end{array}$ & $\begin{array}{l}\text { FISTAROL KS } \\
\text { et al., (2009) [9] } \\
\text { 100 CASES }\end{array}$ & $\begin{array}{l}\text { DOMINGUEZ- } \\
\text { SOTO L et al., } \\
(1994)[10] \\
75 \text { CASES }\end{array}$ \\
\hline $\begin{array}{l}\text { Lichen planus and its } \\
\text { variants } \\
\text { Post inflammatory } \\
\text { hyperpigmentation } \\
\text { Prurigo nodularis } \\
\text { Prurigo simplex Lichen } \\
\text { simplex chronicus } \\
\text { Erythema dyschromium } \\
\text { perstans } \\
\text { DLE } \\
\text { PMLE } \\
\text { Eczema } \\
\text { Morphea } \\
\text { Acne }\end{array}$ & $\begin{array}{l}\text { Melanoma } \\
\text { Seborrheic } \\
\text { keratosis } \\
\text { Acanthosis } \\
\text { nigricans } \\
\text { Melasma } \\
\text { Diabetic } \\
\text { dermopathy } \\
\text { Tinea versicolor } \\
\text { Post inflammatory } \\
\text { hyperpigmentation } \\
\text { Sun exposure } \\
\text { Phototoxic reaction }\end{array}$ & $\begin{array}{l}\text { Post inflammatory } \\
\text { hyperpigmentation } \\
\text { Acne } \\
\text { Lichen planus } \\
\text { Atopic dermatitis } \\
\text { Solar lentigos } \\
\text { Melasma } \\
\text { Ephelides } \\
\text { Café-au-lait spots } \\
\text { Nevus } \\
\text { Melanoma }\end{array}$ & $\begin{array}{l}\text { Nevus } \\
\text { Melasma } \\
\text { Café-au-lait } \\
\text { spots } \\
\text { Addison"s } \\
\text { disease } \\
\text { Peutz-Jeghers } \\
\text { syndrome } \\
\text { Diabetic } \\
\text { dermopathy } \\
\text { Pityriasis } \\
\text { versicolor }\end{array}$ & $\begin{array}{l}\text { Ashy dermatosis } \\
\text { Lichen planus } \\
\text { pigmentosus } \\
\text { Frictional } \\
\text { dermatitis } \\
\text { Pityriasis } \\
\text { versicolor } \\
\text { Pinta. }\end{array}$ \\
\hline
\end{tabular}




\section{REFERENCE}

1. Khanna N, Rasool S. Facial melanoses: Indian Perspective. Indian J Dermatol Venereol Leprol. 2011;77:552-63.

2. Sarkar R, Puri P, Jain RK, Singh A, Desai A. Melasma in men: a clinical, aetiological and histological study. J Eur Acad Dermatol Venereal. 2010;24:768-72.

3. Maize JC, Ackerman AB. Freckle. In: maize jc, ackerman $a b$, editors. Pigmented lesions of the skin. Philadelphia: lea and febiger; 1987:28-30.

4. Ellis FA. Histopathology of lichen planus based on analysis of one hundred biopsy specimens. The journal of investigative dermatology. 1967; 48(2): 143-148.

5. Sehgal VN, Srivastava G, Sharma S, Sehgal S, Verma P. Lichenoid tissue reaction/interface dermatitis: recognition, classification, etiology and clinicopathological overtones. Indian Journal of Dermatol Venereol Leprol. 2011; 77(4): 418-430.
6. Sontheimer RD. Lichenoid tissue reaction/interface dermatitis: clinical and histological perspectives. Journal of Investigative Dermatology. 2009; 129: 1088-1089.

7. Stulberg LD, Clark N, Tovey D. Common hypermigmentation disorders in adults: part ii. Melanoma, seborrheic keratosis, acanthosis nigricans, melasma, diabetic dermopathy, tinea versicolor and postinflammatory hyperpigmentation. Journal of American Academy of Family Physicians. 2003 Nov; 68(10): 19551960.

8. Plensdorf S, Martinez J. Common pigmentation disorders. Journal of american academy of family physicians. 2009 Jan; 79(2): 109-116.

9. Fistarol KS, Itin HP. Disorders of pigmentation. Journal of german society of dermatology. 2010 March; 8: 187-202.

10. Soto DL, Tomoka TH, Memije VE, Arenas R, Franco CR. Pigmentary problems in tropics. Dermatol Clin.1994 Oct; 12(4):777-778. 